\title{
Lifting Kit for Flooded Furnitures: Mechanical Design and Strength Analysis
}

\author{
Muhammad Dzulkifly ${ }^{1, a}$, Raffy Frandito ${ }^{2, b}$, Wildan Rahmawan ${ }^{3, c}$, M. Rafli \\ Ramadhani ${ }^{4, d}$, and Farid Triawan ${ }^{5, e}$ \\ 1,2,3,4,5Department of Mechanical Engineering, Faculty of Engineering and Technology, Sampoerna \\ University, Jakarta 12780, Indonesia \\ 1,2,3,4,5 Department of Aerospace and Mechanical Engineering, The University of Arizona, Tucson, \\ AZ, 85721, USA. \\ efarid.triawan@sampoernauniversity.ac.id
}

\begin{abstract}
Abstrak.
Hampir setiap tahun, bencana banjir menjadi momok banyak negara di dunia, termasuk Indonesia. Saat banjir datang dan merendam rumah, setiap barang dan perabot rumah tangga di dalamnya juga akan terendam banjir. Perabot yang berat dan sulit untuk dipindahkan, terutama peralatan elektronik seperti lemari es, sering direlakan oleh pemiliknya saat terjadi banjir. Untuk mencegah furnitur agar tidak tenggelam, diperlukanlah alat untuk mengangkatnya. Tujuan dari artikel ini adalah merancang alat mekanik yang dapat mengangkat alat elektronik seperti lemari es ke posisi yang lebih tinggi dan untuk menghindari kerusakan akibat banjir. Alat tersebut diharapkan mampu mengangkat lemari es berukuran $100 \times 80 \mathrm{~cm}$ dengan beban maksimal $200 \mathrm{~kg}$. Elevasi alat angkat diatur lebih tinggi dari $50 \mathrm{~cm}$. Perhitungan analisis stres dan kelelahan bahan juga dilakukan untuk mengevaluasi kekuatan struktur. Hasilnya, faktor keamanan yang diperoleh untuk komponen kritis dalam kondisi beban statis dan Lelah menunjukkan nilai lebih dari satu, yang menunjukkan bahwa produk tersebut aman untuk dioperasikan. Selain itu, torsi yang dibutuhkan untuk menghasilkan elevasi juga dibahas pada artikel ini.
\end{abstract}

Kata kunci. alat angkat, dongkrak, perabot kebanjiran, analisis kekuatan, mekanikal desain

\begin{abstract}
.
Almost every year, floods disaster becomes the scourge of many countries in the world, including Indonesia. When the flood comes and submerges the houses, every item and household furniture in it will also be submerged in flood water. Furniture that is heavy and difficult to move, especially electronic equipment such as refrigerators, may be left by the owner when a flood occurs. To prevent the furniture from submerging, a lifting kit is needed. For this reason, the purpose of this work is to design a mechanical tool/kit that can lift or elevate the electronic furniture such as refrigerator to a higher position and avoid the damage caused by flood. The kit is expected to be able to cover a 100 x $80 \mathrm{~cm}$ base of the refrigerator with maximum load of $200 \mathrm{~kg}$. The elevation of the lifting kit is set to be higher than $50 \mathrm{~cm}$. Calculation for the stress and fatigue analysis is also performed to determine the strength of the structure. As a result, the obtained safety factors for the critical components under static and fatigue loading conditions show values of more than one, indicating the product is safe for real operation. In addition, the required torque to produce the elevation is also calculated and discussed.
\end{abstract}

Keywords: lifting tool, jack, flooded furniture, strength analysis, mechanical design analysis 


\section{INTRODUCTION}

Flood disaster is a problem faced by many countries in the world, including Indonesia. The problem of flooding in Jakarta is almost never end. Attempts to end and resolve the flood have spawned an endless debate. Apart from social problems such as displacement due to submerging of houses, disease and economic problems also arise due to flooding which almost always occurs every year in Jakarta.

Jakarta floods are a complex problem, there are many causes, ranging from the geological and geomorphological aspects of the Jakarta which are basin area and flood plain, the morphometry of the 13 river flows that pass through the Jakarta area, to the infrastructure and social behavior of its citizens who often make efforts of flood mitigation becomes difficult to be implemented [1]. Of the many factors that cause flooding, it needs to be realized that main factor causing flooding is heavy rainfall [2].

The problem of flooding in Jakarta continues to increase from time to time. Such conditions cause flooding and development in Jakarta to interact with each other, meaning that flooding can damage development outcomes, but on the other hand, sometimes the development results themselves that become the cause of flooding. Not only snatched casualties but also property, neglected economic cycle, and public services are not running, at the end of 2006 the floods caused entrepreneurs or to suffer losses of up to IDR 2.6 trillion. Most of this figure comes from losses that must be borne due to the interruption of the production process for approximately 7 days during the flood.

Floods also have the risk of raising the price of necessities by 10-20 percent because the distribution of goods is hampered. Based on data from the book Institutional Cooperation Relations in Watershed Management by Omo Rusdiana and his friends, due to the 2002 floods, Jakarta had to lose at least IDR 9.8 trillion [3]. The details are the economic sector loss of IDR 2.5 trillion, transportation and telecommunication IDR 78.5 billion, direct damage IDR 5.3 trillion, indirect damage IDR 2.8 trillion [4]. In addition, the value of losses suffered due to loss of houses is an average of IDR 10 million per house, including the value of property losses, with the consideration that lost houses are generally non-permanent houses along the river. Meanwhile, the amount of damage and losses suffered by the owner whose house was severely damaged, including damage and loss to furniture, equipment, and clothing, is estimated at IDR 20 million per house [5].

To prevent the furniture from submerging, a lifting kit is needed. Generally, lifting kit can function like a jack that can elevate any heavy object above the ground. This kit would be necessary for the house that often hit by the flood to safe the fridge and other electronics so that it would not be submerged into the water flood. Thus, the damage due to the flood can be avoided. For this reason, the purpose of this work is to design a mechanical tool/kit that can lift or elevate the electronic furniture such as refrigerator to a higher position and avoid the damage caused by flood. This proposed design is expected to help people that lives in the area with annual flood season to be prepared to save their furniture with practical and economical approach.

\section{METHODOLOGY}

The development of Lifting Kit requires some boundary conditions, including:

1. The maximum elevatable dimension is $100 \times 80 \mathrm{~cm}$

2. The maximum weight is $200 \mathrm{~kg}$

3. The lifting height is at least $50 \mathrm{~cm}$

The synthesis was done by determining the required features and design to achieve the expected conditions. Furthermore, components such as scissor arms, bolts, and threaded shaft are also determined for the device to achieve the goals safely. 


\subsection{Design Concept}

From the point of view of the effectiveness and possibility of our product working, the design of this product has a similar concept with a scissor jack, in which there would be a shaft or thread lever as a component of adjuster as shown on the Figure 2. This has become the consideration with the product aims to lift heavy household items such as refrigerators. In accordance with the use of the scissor jack, our tool also has an elevation for lifting and lowering goods [6]. The design has been made using Solidworks drawing as shown in the Figures 1 (a) and 1 (b).

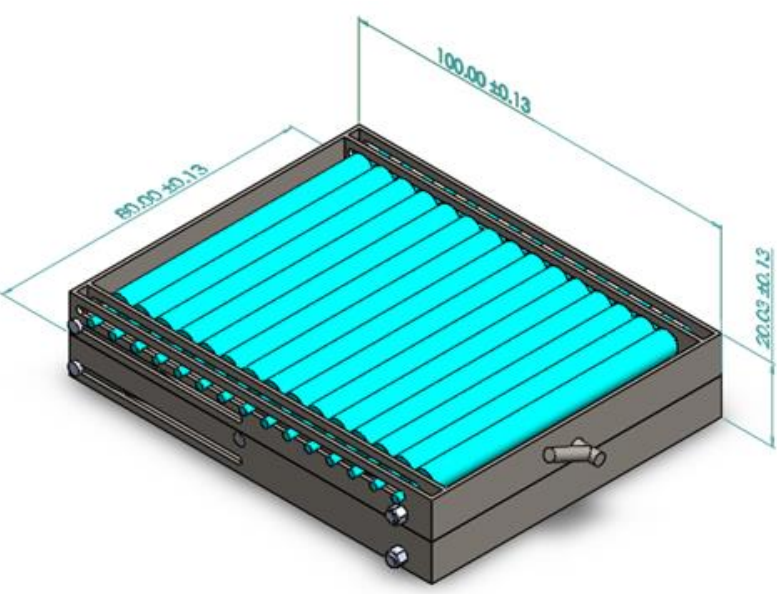

(a)

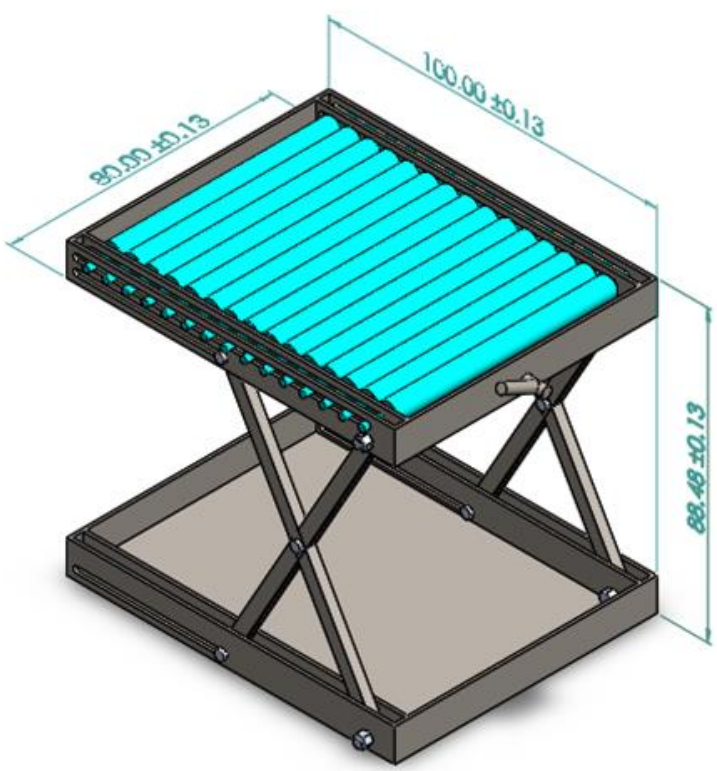

(b)

Figure 1 Final Design Initial Position (a) and Final Design Maximum Position (b)

\subsection{Material Selection}

To meet the expectation of the product needs. Choosing a material also a crucial thing needs to consider. Material selection could be the critical part that could affect the life cycle of a product [7]. Referring to the application and manufacturing process of the product, the most suitable material that can be used is ASTM A36 [8]. Moreover, since the operation of this product is similar to jack (scissor jack), the material used to this product with the jack design could be also similar or the same. The optimization due to cost and durability of the design of scissor jack is by using mild and hot-rolled ASTM A36 Steel [9] [10]. It has excellent welding properties and is suitable for grinding, punching, tapping, drilling, and machining processes [11] [12]. Table 1 is showing the mechanical properties of the ASTM A36 material, while for Table 2 is showing the physical properties of the material. The properties of the material would later be used in the result and discussion for calculating the fatigue and safety factors.

Table 1 Mechanical Properties of ASTM A36 Steel [13]

\begin{tabular}{lll}
\hline Mechanical Properties & Metric & Imperial \\
\hline Tensile Strength, Ultimate & $400-550 \mathrm{MPa}$ & $58000-79800 \mathrm{psi}$ \\
\hline Tensile Strength, Yield & $250 \mathrm{MPa}$ & $36300 \mathrm{psi}$ \\
\hline Elongation at Break (in 200 mm) & $20.0 \%$ & $20.0 \%$ \\
\hline Elongation at Break (in 50 mm) & $23.0 \%$ & $23.0 \%$ \\
\hline Modulus of Elasticity & $200 \mathrm{GPa}$ & $29000 \mathrm{ksi}$ \\
\hline Bulk Modulus (typical for steel) & $140 \mathrm{GPa}$ & $20300 \mathrm{ksi}$ \\
\hline Poisson's Ratio & 0.260 & 0.260 \\
\hline Shear Modulus & $79.3 \mathrm{GPa}$ & $11500 \mathrm{ksi}$
\end{tabular}


Table 2 Physical Properties of ASTM A36 Steel [13]

\begin{tabular}{lll}
\hline Physical Properties & Metric & Imperial \\
\hline Density & $7.85 \mathrm{~g} / \mathrm{cm}^{3}$ & $0.284 \mathrm{lb} / \mathrm{in}^{3}$ \\
\hline
\end{tabular}

\subsection{Design's Component \& Specification}

To obtain the final design of the product, the specification of the component should clearly define. The final design in exploded view could be seen in Figure 2. Moreover, Table 3 is showing the listed components with labeled number and the dimensions. The dimension and specification of the components would be beneficial to use later in the analysis of FBD, stresses, safety factors, and fatigue

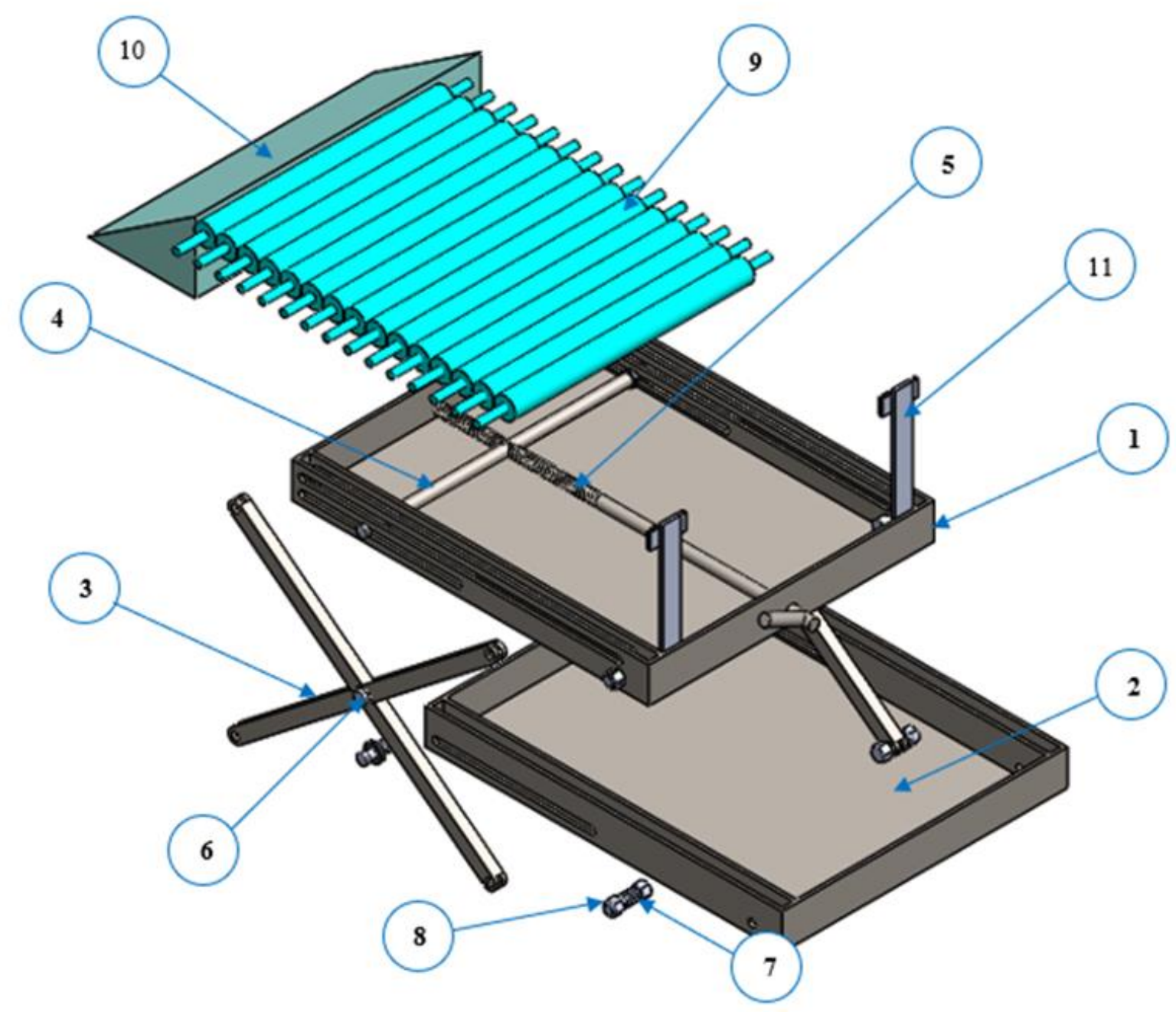

Figure 2 Final Design Exploded View 
Table 3 List of Components Specifications

\begin{tabular}{|c|c|c|c|c|c|}
\hline Num & Components & $\begin{array}{l}\text { Width } \\
\text { (cm) }\end{array}$ & $\begin{array}{c}\text { Length } \\
(\mathrm{cm})\end{array}$ & $\begin{array}{l}\text { Height/thic } \\
\text { kness (cm) }\end{array}$ & Other \\
\hline 1 & Top plate & 80 & 100 & 15 & - \\
\hline 2 & Below plate & 80 & 100 & 15 & - \\
\hline 3 & Arm & 4 & 90 & 1 & - \\
\hline 4 & Pull beam & - & 80 & $\begin{array}{c}3 \mathrm{~cm} \\
\text { diameters }\end{array}$ & $\begin{array}{l}3 \mathrm{~cm} \text { hole diameter } \\
\text { with } 3.5 \mathrm{~cm} \text { pitch }\end{array}$ \\
\hline 5 & $\begin{array}{l}\text { Thread Lever } \\
\text { (Shaft) }\end{array}$ & - & 106 & $\begin{array}{c}5 \mathrm{~cm} \\
\text { diameters }\end{array}$ & $\begin{array}{l}3 \mathrm{~cm} \text { diameter with } \\
3.5 \mathrm{~cm} \text { pitch }\end{array}$ \\
\hline 6 & $\begin{array}{l}\text { Pin joint (in the } \\
\text { middle of the arm) }\end{array}$ & - & 3 & $\begin{array}{c}2 \mathrm{~cm} \\
\text { diameters }\end{array}$ & - \\
\hline 7 & $\begin{array}{l}\text { Screw (for fixed } \\
\text { position) }\end{array}$ & - & - & - & $\begin{array}{c}\text { M1.0x } 1,3 \mathrm{~cm} \\
\text { diameter with } 3.5 \\
\text { cm pitch }\end{array}$ \\
\hline 8 & $\begin{array}{l}\text { Bolt (for fixed } \\
\text { position) }\end{array}$ & - & - & - & $\begin{array}{c}\text { M1.0x } 1,3 \mathrm{~cm} \text { hole } \\
\text { diameter with } 3.5 \\
\mathrm{~cm} \text { pitch }\end{array}$ \\
\hline 9 & Conveyor & - & 80 & $\begin{array}{c}6 \mathrm{~cm} \\
\text { diameters }\end{array}$ & $\begin{array}{l}\text { Inner diameter } 2 \mathrm{~cm} \text {, } \\
\text { outer diameter } 6 \mathrm{~cm}\end{array}$ \\
\hline 10 & Inclined Plane & 80 & 40 & 30 & - \\
\hline 11 & Magnetic Grip & 5 & 40 & 1 & Magnet: $4.5 \times 10 \times 1$ \\
\hline
\end{tabular}

\subsection{Design Operation}

In its development, the product has calculated carefully so that the product has a proper function and is effective in doing several operations that allow to compete in the market. This product is operating like scissor jack mechanism with a thread lever or shaft.

The operation of this product is started with an inclined plane which aims to place the refrigerator on top of the appliance plate. This inclined plane is only placed on the left side of the refrigerator. The reason is because the right side of the refrigerator is used for a screw lever that is used to raise this product. This refers to Figure 2 number 10.

Second, in operation, the person must turn the screw lever on the top plate so that the tool can be raised. In its application, it has calculated the torque or force required for the person to elevates the refrigerator. It has confirmed that the person will not lift too heavy weight when turning the lever. The calculation could be seen in the result and discussion torque analysis. This refers to Figure 2 number 5 .

Third, the appliance also has a conveyor at the top of the plate that makes it easy for the customer to push and place the refrigerator. The plate of the conveyor is made of rubber, so it is not slippery, and the refrigerator do not slip easily. This refers to Figure 2 number 9.

Fourth, when this product featured with conveyor concept, means it should consider with the handle or grip so that the refrigerator on top of this tools do not fall easily when the tool is subjected to vibrations. Therefore, magnetic extensions attached on the side of the refrigerator. The length and curvature of this magnet can be changed according to the needs or dimensions of the refrigerator. This refers to Figure 2 number 11.

It is suggested to place the refrigerator at top of the kit as soon as the customer purchased the product. This is for the sake of ease and practicality. 


\section{RESULT AND DISCUSSION}

\subsection{Free Body Diagram Analysis}

In order to know the value that would exist for the whole scissors arm, an observation towards the whole system is needed. Here, the analysis conducted at the highest and lowest elevation so that the value of the reaction pin at point $\mathrm{C}$ and $\mathrm{E}$ from the Figure 4 (a) \& (b) could be obtained. The value of this reaction force at $\mathrm{C}$ and $\mathrm{E}$ would be used to analyze the scissors arm.

\subsubsection{Analysis on the whole system}

The free body diagram analysis starts with the analysis of the whole system. The system is analysed on both top and bottom position. The external load is obtained from a refrigerator weighs $200 \mathrm{~kg}$ or $1962 \mathrm{~N}$ with 4-point load. In free body diagram analysis on top position, illustrated in Figure 3 (a) and 3 (b), the analysis is done on one side of the lifting kit. This aims to figure out the amount of force exerted from each arm. Therefore, the external load for each side is $100 \mathrm{~kg}$ or $981 \mathrm{~N}$ which is distributed at two positions. The reaction forces in Figure 4 (a) are applied by the scissor arms on top position. For analysis on low position, illustrated in Figure 4 (a) and 4 (b), the analysis is done on both side of the lifting kit. This aims to calculate the amount of force applied on bearing and pull beam. The reaction forces in Figure 4 (b) are applied by the scissor arms on low position.

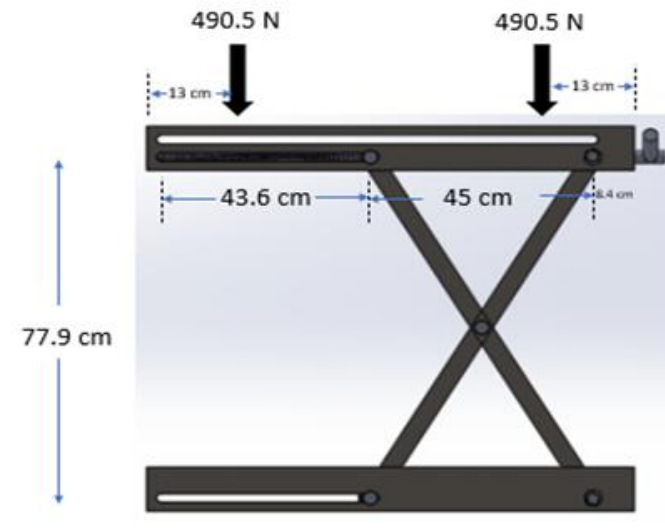

(a)

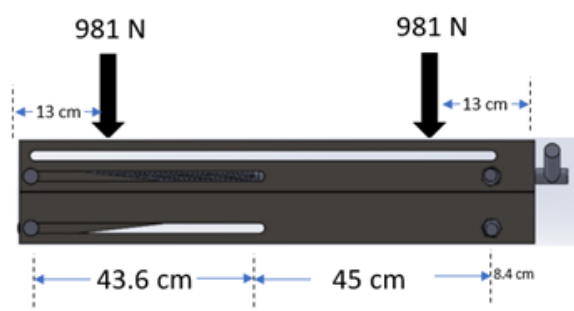

(b)

Figure 3 FBD Analysis of the whole system on (a) top position and (b) low position

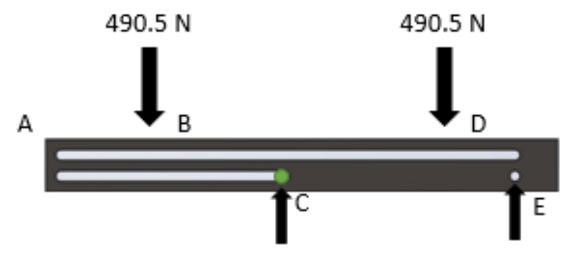

(a)

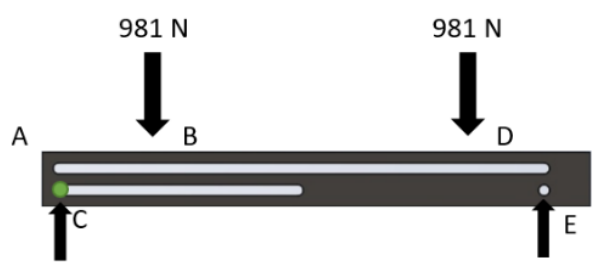

(b)

Figure 4 FBD Analysis of top plate on (a) top position and (b) low position 


\subsubsection{Internal forces on arms}

Internal forces observation conducted to determine the maximum shearing force and bending moment acting on the arms. The value of maximum shearing force and bending moment would later be used to calculate the stress concentration acting on each arm. Here the observation towards each scissors arm needs to be conducted first using the reaction force that is already obtained from the FBD of whole system analysis. A static analysis is conducted to find the unknown acting on each scissors arm. The scissor arm 1 on high position, illustrated in Figure 5 (a), shows that the maximum force is located at center pin $\mathrm{G}$, that is $854.58 \mathrm{~N}$, while on low position, illustrated in Figure 5 (b), the maximum force is located at center pin $\mathrm{G}$ and pin $\mathrm{H}$, that is $5563.6 \mathrm{~N}$. The same case is applied for scissor arm 2. On high position, illustrated in Figure 6 (a), the maximum force is located at center pin $\mathrm{G}$, that is $854.58 \mathrm{~N}$, while on low position, illustrated in Figure 6 (b), it is located at center pin $\mathrm{G}$ and pin $\mathrm{H}$, that is $5563.6 \mathrm{~N}$.

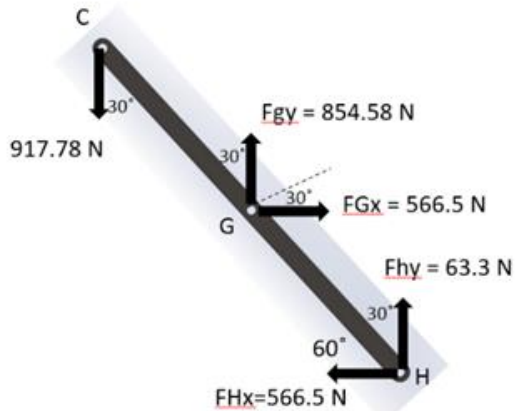

(a)

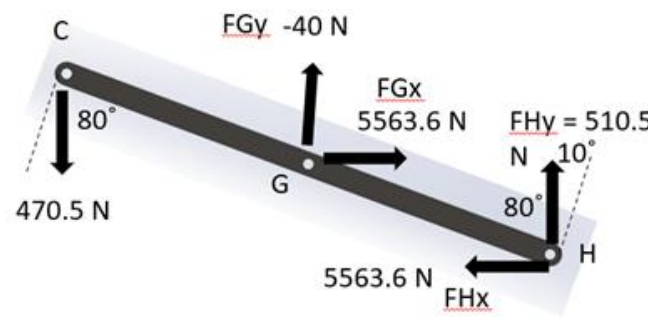

(b)

Figure 5 Internal forces on scissor arm 1 on (a) top position and (b) low position

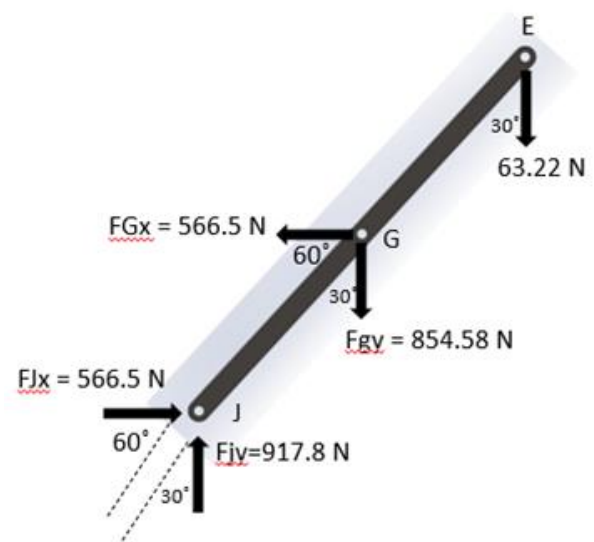

(a)

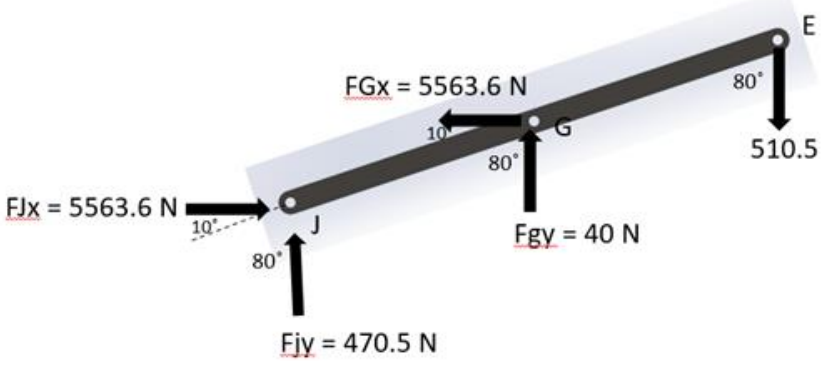

(b)

Figure 6 Internal forces on scissor arm 2 on (a) top position and (b) low position

The force member would be used to determine the bending and shear stress generated on the scissor arms. The calculation of stress would be used in determining the safety factor of each arms on each position.

\subsubsection{Reaction forces in pull beam}

The value that is generated at both end of the rod is the value obtained from the FBD analysis of scissors arm. Generally, it is the value of the $F_{J_{x}}$ shown on the Figure 6 (b). Figure 7 shows the free body diagram of the pull beam resulting from the scissor arm analysis. This result could also be used to determine the value of torsion required to lift the system by human. 


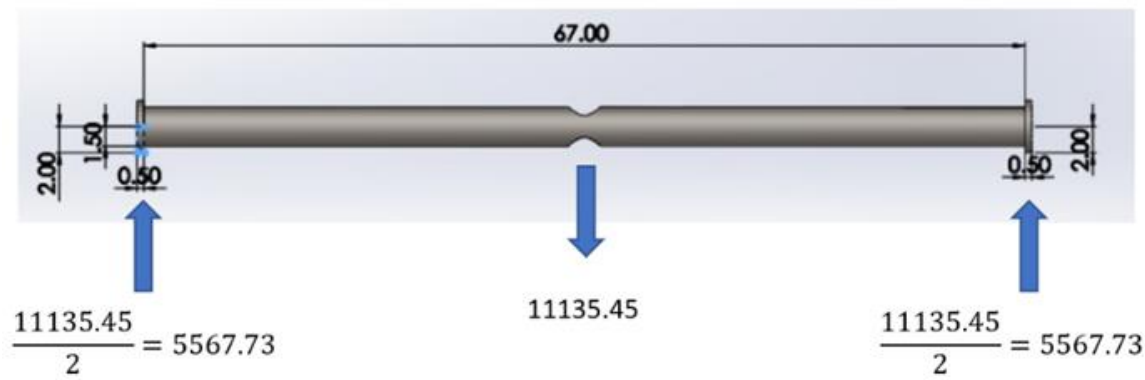

Figure 7 Pull Beam FBD

\subsection{Stress Analysis and Safety Factor}

Stress analysis is required to determine the safety factor. The analysis is done on each body of the system. The analysis is done first on scissor arms, center pin, threaded shaft, and pull beam. First, the stress analysis is done on scissor arms at highest and lowest position. Using forces obtained from free-body diagram analysis, the stress can be obtained by calculating the normal force with respect to the body and the cross-sectional area. Then, shearing force diagram and bending moment diagram are obtained to calculate the stress. After the stress is obtained, maximum-shearing-stress criterion is used to find out the safety factor. The shearing force diagram and bending moment diagram on scissor links at highest and lowest position are illustrated in Figure 8, as well as table 4 for calculation results. Table 4 shows that link 1 at highest position is the critical among the other links, with 1.56 of safety factor. Even though it is the most critical, it is still safe to use under expected load.
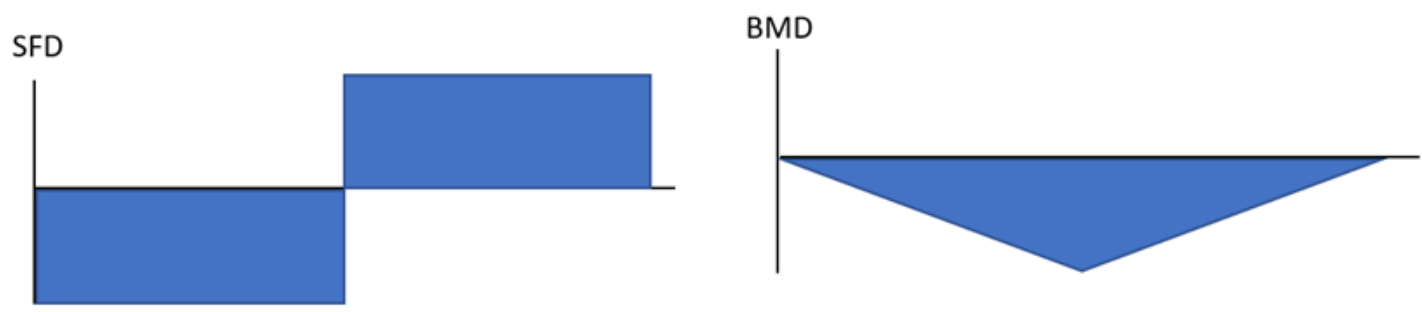

Figure 8 SFD and BMD Scissors Arms

Table 4 Stress Calculation Result on Link

\begin{tabular}{lcccc}
\hline Links & $\begin{array}{l}\text { Link } \\
\text { (highest) } \\
\text { position }\end{array}$ & $\begin{array}{l}\text { 1 } \\
\text { (highest } \\
\text { position) }\end{array}$ & $\begin{array}{l}\text { Link } \\
\text { (lowest } \\
\text { position) }\end{array}$ & $\begin{array}{l}\text { Link 2 (lowest } \\
\text { position) }\end{array}$ \\
\hline $\begin{array}{l}\text { Maximum shearing } \\
\text { force (N) }\end{array}$ & 458.95 & 31.65 & 463.5 & 502.75 \\
\hline $\begin{array}{l}\text { Maximum bending } \\
\text { moment (Nm) }\end{array}$ & 206.53 & 14.25 & 208.51 & 226.25 \\
\hline $\begin{array}{l}\text { Tensile/Compression } \\
\text { Stress (MPa) }\end{array}$ & 5.3 & 7.5 & 37.03 & 37.06 \\
\hline $\begin{array}{l}\text { Maximum normal } \\
\text { stress at a point } \\
\text { (MPa) }\end{array}$ & 165.23 & 11.4 & 166.8 & 189.98 \\
\hline $\begin{array}{l}\text { Maximum normal } \\
\text { stress (MPa) }\end{array}$ & 159.93 & 3.9 & 129.77 & 143.92 \\
\hline $\begin{array}{l}\text { Maximum shearing } \\
\text { stress (MPa) }\end{array}$ & 79.97 & 1.95 & 64.89 & 71.96 \\
\hline $\begin{array}{l}\text { Safety factor } \\
\text { farim }\end{array}$ & 1.56 & 64.1 & 1.92 & 1.74 \\
\hline
\end{tabular}


The safety factor for other components is also calculated. Using M30 thread, the stress analysis of threaded shaft is done. This thread has dimension of $30 \mathrm{~mm}$ major diameter and $3.5 \mathrm{~mm}$ coarse pitch. Assuming coefficient friction to be 0.08 , the stress analysis starts with calculating axial stress in screw body, maximum nominal shear stress, bearing stress, bending stress, and finally von Mises stress. The safety factor for threaded shaft is obtained at 1.4, indicating this is one of the most critical parts.

The stress analysis of center pin is obtained by calculating the resultant force from scissor arms, which is about $5472 \mathrm{~N}$. Using $10 \mathrm{~mm}$ screw, the shearing stress experienced by this pin is about $69.7 \mathrm{MPa}$. While the yield strength for $10 \mathrm{~mm}$ screw is $118.2 \mathrm{MPa}$, the safety factor is obtained at 1.7 , which is still safe to operate.

Bearing is a part to connect scissor arm with pull beam. The analysis starts with calculation of shearing force, that is about $\mathrm{N}$, then the calculation the minimum diameter of bearing that will withstand such shearing force. Therefore, the bearing used is $15 \mathrm{~mm}$ diameter with safety factor of 2 .

Finally, the calculation of pull beam, where it is predicted to be the most critical part, is done. The beam has rectangular cross section with screw hole for threaded shaft. Here, the dimension of the cross section is $50 \mathrm{~mm}$ height and $30 \mathrm{~mm}$ depth. The stress of this beam is resulted from force from scissor links and the threaded shaft, making this beam is in bending. The maximum bending moment due to these forces is about $5567 \mathrm{~N}$, so the maximum stress experienced by this beam is about 178 $\mathrm{MPa}$. Therefore, the safety factor for pull beam is 1.4 , which is the most critical part in this device. Table 5 shows the safety factor of threaded shaft, center pin, bearing, and pull beam.

Table 5 Safety Factor of Other Component

\begin{tabular}{ccccc}
\hline Part & $\begin{array}{c}\text { Threaded } \\
\text { shaft }\end{array}$ & Center pin & Bearing & Pull beam \\
\hline Safety factor & 1.4 & 1.7 & 2 & 1.4 \\
\hline
\end{tabular}

\subsection{Fatigue Analysis}

\subsubsection{Marin Factor}

Fatigue analysis is beneficial to be conducted so that the life prediction of the product could be obtained. The step of generating the fatigue analysis generally start from defining Marin factor to obtain the stress endurance, calculating the stress concentrate, and calculating the fluctuating stress to obtain the $\sigma_{\mathrm{m}}$ and $\sigma_{\mathrm{a}}$ to be used for forecasting life cycles of the system. The values of Marin Factors are shown in table 6.

Table 6 Marin Factor Values

\begin{tabular}{lc}
\hline \multicolumn{1}{c}{ Marin factor } & Value \\
\hline Surface factor $\left(\boldsymbol{k}_{\boldsymbol{a}}\right)$ & 0.847189236 \\
\hline Size factor $\left(\boldsymbol{k}_{\boldsymbol{b}}\right)$ & 0.857829515 \\
\hline Load factor $\left(\boldsymbol{k}_{\boldsymbol{c}}\right)$ & 1 \\
\hline Temperature factor $\left(\boldsymbol{k}_{\boldsymbol{d}}\right)$ & 1 \\
\hline Reliability factor $\left(\boldsymbol{k}_{\boldsymbol{e}}\right)$ & 1.45 \\
\hline Miscellaneous factor $\left(\boldsymbol{k}_{\boldsymbol{f}}\right)$ & \\
\hline
\end{tabular}

The material used settled for the pull beam is ASTM A36 which has a value of $S_{u t}=550 \mathrm{MPa}$. The ultimate strength $\left(S_{u t}\right)$ would be used to determine the surface factor and the value of the typical material on a beam test. The surface factor of the rod is assumed to be experienced a cold drawn or machined since it is one of the tubular bodies. The rod also experienced a bending moment due to the 
force member, therefore the size factor would not be equal to 1 and the load factor would be equal to one. The rest of Marin factor is assumed to be equal to 1 since there are no significant special treatment on it.

The endurance strength could be obtained using the Marin factor, the formula used is provided in Equation 1:

$$
S_{e}=k_{a} k_{b} k_{c} k_{d} k_{e} S_{e}^{\prime}
$$

For ASTM A36 material which has $550 \mathrm{MPa}$ of ultimate tensile strength $\left(S_{u t}\right)$, the endurance strength $\left(S_{e}^{\prime}\right)$ is half of it, that is $275 \mathrm{MPa}$. After calculating with Marin Factors, the new endurance strength $\left(S_{e}\right)$ is obtained, $199.855 \mathrm{MPa}$. The value of endurance strength found from the Marin factor would be used to calculate the life cycles.

For this system, the most critical component design is the pull beam where the thread is attached. Therefore, the fatigue analysis would be focused on this component design. The consideration also due to the safety factor of the pull beam. The pull beam where the thread attached having the nearest value to one in which $n=1.4$. Thus, it may have tendency to be the component that is fail first.

\subsubsection{Stress Concentration}

The stress concentration is needed to be calculate since the pull beam where the thread attached having a notch where the concentration stress may appear. The method of obtaining the stress concentration may be obtained by referring to Shigley's book chapter 6 [14]. Using Equation 2, where $\mathrm{q}$ is notch sensitivity and $\mathrm{k}_{\mathrm{t}}$ is stress-concentration factor, it is found out that the stress concentration is 1.45. The stress concentration is illustrated in Figure 9.

$$
k_{f}=1+q\left(k_{t}-1\right)
$$

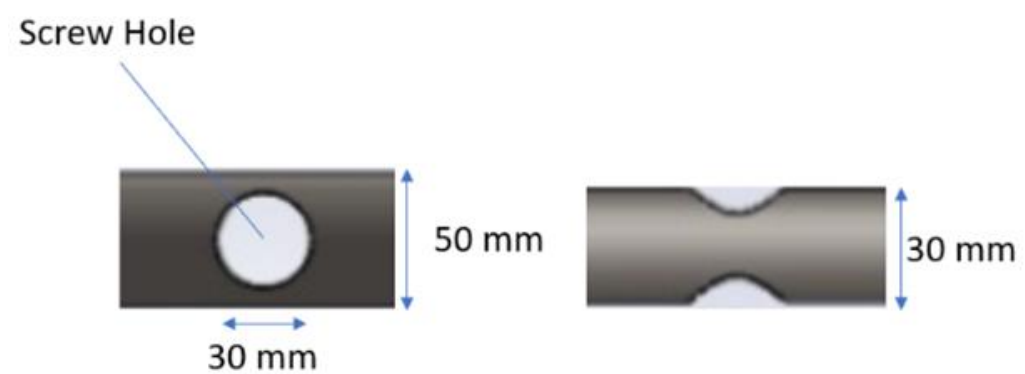

Figure 9 Notch on Pull Beam

\subsubsection{Fatigue Factor}

Fatigue factor is beneficial for the engineers in designing a product so that the life cycles of the product can be predicted. The fatigue factor could be obtained by 4 different failure criterions. For this system, the mod - Goodman failure criterion is applied since the observed critical point having a bigger tendency on bending. The mod - Goodman failure criterion also beneficial to use in this product since the determined known values could be obtain [15].

Calculating the fluctuating stress is done by using Equations 3 and 4:

$$
\sigma_{a}=\frac{k_{f}\left(F_{\max }-F_{\min }\right)}{2 A}
$$




$$
\sigma_{m}=\frac{k_{f}\left(F_{\max }+F_{\min }\right)}{2 A}
$$

Where $F_{\max }$ and $F_{\min }$ are forces obtained from scissor arm analysis. These calculations result in amplitude stress $\left(\sigma_{a}\right)$ and midpoint stress $\left(\sigma_{m}\right)$ which would be used to calculate the fatigue safety factor using the mod - Goodman failure criterion shown in Equation 5 below:

$$
\frac{\sigma_{a}}{S_{e}}+\frac{\sigma_{m}}{S_{u t}}=\frac{1}{n_{f}}
$$

The value of maximum force, minimum force, amplitude stress, midpoint stress, and fatigue safety factor are shown in Table 7.

Table 7 Forces, stresses, and fatigue safety factor

\begin{tabular}{lc}
\hline Maximum force $\left(\boldsymbol{F}_{\max }\right)$ & $11135.45 \mathrm{~N}$ \\
\hline Minimum force $\left(\boldsymbol{F}_{\min }\right)$ & $1133 \mathrm{~N}$ \\
\hline Midpoint stress $\left(\boldsymbol{\sigma}_{\boldsymbol{m}}\right)$ & $14.82 \mathrm{MPa}$ \\
\hline Amplitude stress $\left(\boldsymbol{\sigma}_{\boldsymbol{a}}\right)$ & $12.09 \mathrm{MPa}$ \\
\hline Fatigue safety factor $\left(\boldsymbol{n}_{\boldsymbol{f}}\right)$ & 11.44 \\
\hline
\end{tabular}

It is found out that the fatigue factor is 11.44 or exceeded 1 . Therefore, our system may be concluded having and infinite cycles since the most critical component design having a fatigue factor bigger than 1 .

\subsection{Torque Analysis}

The analysis towards the thread shaft is conducted on a low position of the system where the force with respect to the $\mathrm{x}$-axis is the highest. The specification of the thread lever is mentioned on the Table 3 with the design provided on Figure 10.

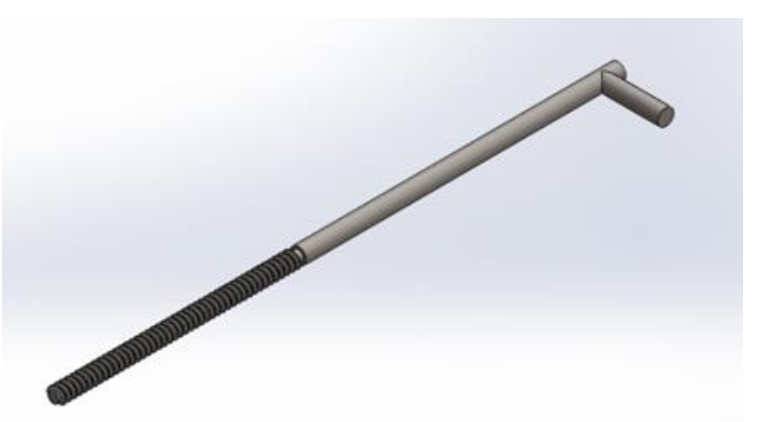

Figure 10 Thread Lever (Shaft)

The torque analysis would focus on the thread shaft component of the design. The torque analysis is conducted to determine the required force to elevate the system by human. The method of analysis is done by assuming the friction coefficient $(f)$ is 0.08 . The analysis towards the required torque is also conducted as if the shaft is placed on the bottom of the system. 


$$
T_{R}=\frac{F d_{m}}{2}\left(\frac{1+\pi f d_{m}}{\pi d_{m}-f l}\right)
$$

where,

$$
\begin{array}{ll}
T_{R} & =\text { required torque } \\
d_{m} & =\text { mean diameter } \\
f & =\text { friction coefficient } \\
l & =\text { lead }
\end{array}
$$

Calculated using the Equation 6, the torque required to elevate the system is $\mathbf{2 5 . 1 3} \mathbf{~ N m}$. The value could be adjusted depending on the length of the thread lever arms. The longer the arms would help a person in reducing the required power to elevate the system.

\section{CONCLUSION AND RECOMMENDATION}

A design component drawing and the analysis of statics and dynamics load are discussed in this journal. The design featured a pull beam and thread shaft where is the most critical part of its proposed design. This lifting kit for flooded electrical furniture is considered a safe design referring to the component safety factor obtained in component 4 is above 1 . Moreover, the calculation of each component safety factor also resulting in an above 1 value. This proposed design approved that the life cycle is infinite based on the calculation of the fatigue analysis. The product is expected to lift a fridge to about $90 \mathrm{~cm}$ from the ground. The subjected fridge is assumed to have 200kg weight, so the human should produce the torque in approximately $25.13 \mathrm{Nm}$. Moreover, the product could be a reference as a new idea for a lifting kit household to help people save their household items. Further research towards the design may suggest because the observation, optimization, and analysis are conducted on paper and by theorem. It may open for further optimization to have the most precise size of the parts which suitable on the market.

\section{REFERENCES}

[1] S. P. Nugroho, "EVALUASI DAN ANALISIS CURAH HUJAN SEBAGAI FAKTOR," Sains \& Teknologi Modifikasi Cuaca, vol. 2, pp. 91-97, 2002.

[2] D. R. Prabawadhani, B. Harsoyo, T. H. Seto and B. R. Prayoga, "HUJAN PENYEBAB BANJIR DI WILAYAH DKI JAKARTA DAN SEKITARNYA," Sains \& Teknologi Modifikasi Cuaca, vol. 17, pp. 1-47, 2016.

[3] O. Rusdiana, Hubungan Kerjasama Institusi Dalam Pengelolaan Daerah Aliran Sungai : Kasus DAS Ciliwung, Fakultas Kehutanan Institut Pertanian Bogor, 2003.

[4] N. Yuhanivia and H. Andreas, "PERTAMBAHAN estimasi KERUGIAN Ekonomi AKIBAT banjir Dengan Pengaruh Penurunan TANAH di jakarta," Journal Geografi Gea, vol. 17, no. 2, 2017.

[5] Badan Perencanaan Pembangunan Nasional, Laporan Perkiraan Kerusakan dan Kerugian Pasca Banjir Awal Februari 2007 di Wiliayah JABODETABEK (Jakarta, Bogor, Depok, Tangerang, dan Bekasi), 2007: Kementerian Perencanaan Pembangunan Nasional Republik Indonesia. 
[6] M. R Patil, "DESIGN AND ANALYSIS OF SCISSORS JACK," International Journal of Mechanical Engineering and Robotics Research, vol. IV, p. 9, 2015.

[7] R. Hawileh, H. Tabatani, A. Abu-Obeidah, J. Balloni and A. Rahman, "Evaluation of the LowCycle Fatigue Life in Seven Steel Bar Types," Journal of Materials in Civil Engineering, vol. 28, p. 5, 2016.

[8] C. Sastry, P. Hariharan, M. P. Kumar and M. M. Manickam, "Experimental investigation on boring of HSLA ASTM A36 steel under dry, wet, and cryogenic environments.," Materials and Manufacturing Processes, vol. 34, pp. 1352-1379, 2019.

[9] D. Dhamak, D. Bajaj, V. Aher and G. Nikam, "Design and Strandardization of Scissors Jact to Avoid Field Failure," IJARIIE, vol. I, no. 3, 2015.

[10] E. Fonsesca and A. Reguly, "The use of ultrasound measurement technique for the evaluation of mechanical properties of the ASTM A36 steels," Journal of the Brazilian Society of Mechanical Sciences and Engineering, vol. 33, no. 2, pp. 212-217, 2011.

[11] Y. HIGASHIDA, D. BURK and F. L. JR, "Strain - Controlled Fatigue Behavior of ASTM A36 and A514 Grade F Steels and 5083-0 Aluminum Weld Materials," WRC Bulletin 191, 1978.

[12] A. I.S and E. E, "Effect of Arc Welding Current on the Mechanical Properties of A36 Carbon Steel Weld Joints," SSRG International Journal of Mechanical Engineering (SSRG - IJME), vol. II, no. 9, 2015.

[13] US Standards, "ASTM A36 Steel Properties, Modulus of Elasticity, Yield Strength, Material Density, Hardness \& Equivalent," Theworldmaterial, 2021. [Online]. Available: https://www.theworldmaterial.com/astm-a36-steel/. [Accessed 26 April 2021].

[14] R. G. Budynas and J. K. Nisbett, Mechanical Engineering Design, New York: McGraw - Hill Companies, Inc., 2011.

[15] S. Zulaikah, W. H. Rahmanda and F. Triawan, "Foldable Front Child-Seat Design for Scooter Motorcycle: Strength Analysis Under Static and Dynamic Loading," International Journal of Sustainable Transportation Technology, vol. 3, no. 2, 2020. 